\title{
Accounting principles and presumptions in agreement with environmental sustainability
}

Disclosure of companies' environment-related accounting data is a new operational area for accountants; for that to happen, it is essential to establish a concordant understanding between accounting principles and grounds and those of sustainability. This kind of knowledge achievement unrolls a methodology with exploratory and explanatory means which aims to understand accounting operation regarding sustainability legal premises, taking into account the organization's economic purpose. It's necessary to acknowledge that both accounting branches, traditional and environmental, anchor on equally valid theoretical grounds which are feasible to blend and develop useful information to accounting practitioners. The obsolete view that environmental impacts resulting from organizational activities should be regarded as a side effect and dealt with by society is no longer acceptable. Brazilian environmental legislature already states as mandatory to organizations to prevent, limit and recover all negative consequences of their operation. We conclude from that, that accountants must comprehend the assessment of accounting principles and grounds for environmental matters, which is consequently relevant to the connection of the theoretical concepts which the Brazilian environmental accounting is subjected to.

Keywords: Sustainability; Accounting principles; Environmental Accounting.

\section{Princípios e premissas contábeis de acordo com a sustentabilidade Ambiental}

\begin{abstract}
A evidenciação contábil dos fatos de cunho ambiental das entidades é uma nova área de operacionalização para os contabilistas; para tanto, é fundamental o entendimento harmônico entre os princípios e fundamentos da contabilidade e os da sustentabilidade. A consecução desse conhecimento perpassa uma metodologia com fins exploratórios e explicativos cujo objetivo é a entender a operacionalização contábil frente ao embasamento jurídico da sustentabilidade ambiental, sem desconsiderar a finalidade econômica das entidades. Entendemos que as bases teóricas sob as quais ambas as vertentes contábeis, tradicional e ambiental, se ancoram são igualmente válidas e possiveis de harmonização para geração de informações úteis aos usuários da contabilidade. A antiga visão de que os impactos ambientais decorrentes das atividades empresariais eram externalidades a serem suportadas por todos não é mais tolerável socialmente. A legislação ambiental brasileira já estabelece a obrigação dessas entidades em prevenir, limitar e recuperar os reflexos ambientais negativos que causam em suas operações. Disso depreende-se que os contabilistas devem compreender a aplicação dos princípios e fundamentos contábeis para fatos de natureza ambiental, o que se torna relevante à conexão dos conceitos teóricos aos quais se sujeita a contabilidade ambiental no Brasil.
\end{abstract}

Palavras-chave: Sustentabilidade; Princípios Contábeis; Contabilidade Ambiental.

Topic: Desenvolvimento, Sustentabilidade e Meio Ambiente

Reviewed anonymously in the process of blind peer.
Received: $10 / 08 / 2018$

Approved: 24/09/2018
André Luís Oliveira Feitosa

Universidade Federal de Sergipe, Brasil

http://lattes.cnpq.br/6189914665954654

profandrefeitosa@hotmail.com

Antônio Carlos dos Santos

Universidade Federal de Sergipe, Brasil

http://lattes.cnpq.br/6329492314899700

http://orcid.org/0000-0002-7255-0525

acsantos12@uol.com.br
Referencing this:

FEITOSA, A. L. O.; SANTOS, A. C.. Accounting principles and presumptions in agreement with environmental sustainability. Revista Ibero Americana de Ciências Ambientais, v.9, n.7, p.296-307, 2018. DOI: http://doi.org/10.6008/CBPC2179-6858.2018.007.0028 


\section{INTRODUCTION}

This article shares a common interest in the academy to understand and contribute to the paradigm of the relationship of men and nature in their economic organizations, more specifically, to recognize the application of the principles and presumptions of Accounting to the disclosure of environment-related accounting data. Since Environmental Accounting is a relatively new study branch in Brazil, it has still been sparsely represented in regard to teaching resources and productive activities nationwide. The main objective is to answer the following matter: are the basic Accounting principles and presumptions valid and applicable when operated in registers of companies' environment-related accounting data?.

The economic activity, studied in Economy, regulated by Law and managed by Administration, is accomplished by applying equity capital from several sources, already described by theorists of classical economy (economic, technological, natural and human) to enable the production of goods, whose price determination will result in profit after its commercialization or consumption. Accounting is the science in charge of studying, measuring, analyzing and demonstrating the interaction between these elements and which, subsequently, are used as subsides to the application in management systems, economic theorization and changes to legislation. The convergence of these four social sciences applied to the functioning of the production system, historically, has been around since Mercantilism and continues, even more entrenched, with the production systems that have followed it.

It's widely widespread that economic organizations have acquired obligations that surpass the simple production of goods and services to the market. Owing to environmental changes that their operation causes to the biosphere, the environmental impacts of an organization should not be disregarded in their management strategies. The environmental responsibility carried by these companies is perceived, today, as an element of good administration to the management of risks which are increasingly regulated by the public power and accompanied by consumers (CERQUEIRA, 2004; NASCIMENTO et al., 2008). Hence, these are the economic reasons that stop entrepreneurs from implementing changes to their corporations, that is, the apprehension of the economic effects of how environmental responsibility mismanagement might affect their activities.

The collective demands to face and solve these matters have urged for an environmental approach in several branches of science. The area of human sciences has responded to these demands by developing Environmental Law (EL), Green Economy (GE), Environmental Economic Systems (EMS) and Environmental Accounting (EA). Each of these disciplines is taught to professionals who act in the management of economic and productive organizations. The objective in each area is to integrate elements of environmental sustainability to the productive agents, minimizing their impacts and responding to the social demands of promoting greater social equity and environmental preservation. These characteristics had been left out the agenda of the holders of economic power, nevertheless these have been shown to be more present in the remaining areas of society. 
With reference to the entrepreneurial strategies, its efficacy and efficiency, these fields of knowledge operate in an intimate system of corroboration and exchange. Thus, the introduction of environmental sustainability in the organizational atmosphere has also brought to Accounting the environmental discipline which aims to study, measure, analyze and economically demonstrate the environmental impacts of productive activities and actions taken by companies to minimize them, generating the Environmental or Social and Environmental Balance. By analyzing this data, managers, in a special way, develop appropriate strategies of performance and the entities inform the results to any external agent that may interest, the society and the State, in other words, the level of environmental responsibility they have achieved (SILVA, 2008).

The attainment of the intended outcomes out of this process permeates through the teaching of necessary know-how to its application, id est, educational forms, methods and strategies that end up capacitating accountants with techniques and behavioral changes that focus on approaching, understanding and working with environmentally related information. It is a completely new perspective to a professional group whose foundation and development were exclusively based on the precepts of deriving and providing economical profit to those who have hired them.

Economic profit is described by Smith (1985) as a product of the interaction of the factors of production: capital, work and land (or natural capital). The study of these factors constitutes the theoretical groundwork used in the Economic Science, specially to the use of macro or microeconomic targets. However, in the organization's routine, these concepts not only fail to be tangible, but also lack quantification to the administration and management of factors of production within organizations, as well as being directed to generate profit. On that matter, it was the Economic Science to transfer this theoretical foundation of economy to practical elements of day-to-day operationalization

The traditional accounting of factors of production is specially guided to capital approach (SMITH, 1985). This is the central element of the constitution of companies' equity and what the most part of accounting is targeted to (SÁ, 2002). This means being aware of the elements of different equity accounts over all the existing and applicable taxes to the companies' activities, charges and rules in labor legislation, the classification of direct and indirect costs, its allocation and apportionment to each type of produced goods so that accounting demonstrations are elaborated.

Once the demonstrations are elaborated, a series of economic indicators are extracted from them. The speed at which companies' economic data have been made available has enabled a higher use of those indicators, since their applicability depends on their correspondence to the equity components at the moment they are acknowledged, working as the foundation to managers' decision-making processes regarding capital allocation available to companies (NEVES, 2013). Therefore, a pattern must be followed in order to standardize the accounting process. Thus, economic data among different organizations might be equally understood and compared. To achieve the standardization, the accounting sciences have basic normalized principles which must be followed by any accounting professional at any institution, under administrative, civil or even penal penalties. 
Considering the focus over capital and equity, the establishment and theoretical development of accounting principles were addressed to them. Environment-related elements have different characteristics when compared to economic or entity-related ones. The innovation to the accounting tradition consists on translating into the economic language, using a highly quantitative tendency, elements which are mainly focused on a qualitative reference. Acknowledging, classifying, measuring and demonstrating equity facts from the organizational activity related to environmental sustainability, these facts are called environmental assets and liabilities (CONSENZA, 2012).

Thereby, the traditional accounting, anchored in historical and normalized presumptions, needs to be updated and comprise the contemporary social challenges. This means all elemental principles in accounting must be made adequate to regulate the environmental accounting disclosure or to be adapted to it, so that they enable the same standardization characteristics among organizations about their economyand environment-related information.

The urgency on the environment-related matters, either when it comes to their economic value or their repairing costs, has made organizations and governments think of new strategies which address to and respond to these questionings. In this regard, measures concerning environmental responsibility "cannot be postponed in the companies' internal extent and must be contemplated in the accounting activity as a whole" (CONSENZA, 2012).

In 2004, the Department of Higher Education from the National Board on Education, in cooperation with the Accounting Federal Board, issued a Resolution of number 10/2004, which presents the mandatory and optional contents on Higher Education courses in Accounting in Brazil. One of the purposes of this resolution is to answer to the need professionals have to accompany the changes that had already been taking place in other countries. Thus, the approach of the environmental matter in accounting was inserted in that moment in graduation courses in Brazil.

Companies which aspire to adhere to nice practices of management and environmental responsibility, must include in their financial demonstrations the environmental assets and liabilities, as well as investments in processes, damage control or pollution elimination technology and elements that reflect their performance aims to mitigate problems; this sort of knowledge must be registered following general leading principles which guarantee the utility, correspondence and uniformity of the accounting information.

These other elements to be incorporated to the accounting demonstrations, the environmental ones, are reinforced from the examinations of Gomes et al. (2012), by reason of, according to the author, the future information holders, the accountants and the corporative decision makers, the administrators, should not overlook the environmental variable in their educational process. In other words, the organizations need professionals whose practice incorporate the formulation and nourishment of environmental management systems and their absence or insufficiency constitutes an obstruction to the process. Bebbington et al. (1994) claims that the poor disclosure of environmental information in accounting demonstrations is a result of the educational process inadequacies: it does not prepare accountants to the challenges of the environment, consequently, it limits their technical capability to measure, to count and to demonstrate information that 
results in the elaboration of the Environmental balance of the companies. The execution of all these accounting activities depend on a normative system for interpretation and register, therefore, it is mandatory that the basic accounting principles and presumptions are comprehended and analyzed concerning their validation to this new tool for accounting of production activities: the environment.

\section{MATERIALS E METHODS}

Considering the guide matter, this study is characterized regarding its ends as explanatory of a qualitative approach, situated in a meeting point between the sciences: economic, accounting, environmental and law. Which, regarding methodology, grants it an interdisciplinary character (VASCONCELOS, 2002; GIL, 2009). The focus of the issue is the verification of the validation and the applicability of the constituent principles of the Accounting Science, which historically correlates with the economic theories and are anchored in the national legal system, with environmental practices accepted by sustainability theories.

The core of the article delimits the research in the principles of accounting and its applicability on the organizations' environment-related elements designated to accounting disclosure. On that subject, the research presents as a normative, documental and bibliographic analysis and an epistemological confrontation between accounting principles and the presumptions of environmental sustainability. The principles owing to the Brazilian juridical elements which anchor the regulations of accounting in the country and ordered by the Federal Accounting Board; and the presumptions by reason of the theoretical foundations which guide the environmental sustainability, its functions, objectives and practices, described in the Agenda 21. All these materials are listed in the item of number five, bibliographical references, and are indicated in discussions in the following item.

\section{THEORETICAL DISCUSSION}

The Accounting Science has a specific study object which is the organizations' equity, its dynamic creates distinct phenomenona of qualitative and quantitative ambit, and their comprehension aims to produce and share useful information to managers' command and decision-making mechanisms in the organizations. This process is subjected to a specific methodology of operationalization and study, both anchored in fundamental and guiding rules, the accounting principles (SÁ, 2002; NEVES, 2013). According to the Resolution 750/93 of the Accounting Federal Board (AFB) in its second article:

The Fundamental Principles of Accounting represent the essence of the doctrines and theories related to the Accounting Science, in accordance to the predominant understanding of the scientific and professional universes in our country. The object of Accounting in its most ample meaning as a social science is the organizations' equity.

This statute stablishes the foundation on which all the accounting phenomena must be studied, operationalized, demonstrated and comprehended. The fundamental principles of accounting were advanced over the development of this science which has origins, originally, back to the end of fifteenth century (SÁ, 2002). In the meantime, the phenomena which affected the entities' equity, and consequently, 
creation of wealth, were strictly considered from a social and economic scope. And the understanding and application of the accounting principles developed and conciliated around those axes.

Considering Smith's economic theory (1985), wealth creation depends on the interaction between the capital (accumulated economic sum), the work (human element) and the land (necessary natural resources). Traditionally the system of production in modern societies developed giving more emphasis to the two first elements, capital and work. The focus of the Accounting Doctrine is the capital as the cause that creates and where entities' equity originates from, either in its quantitative and/or qualitative aspects, to the production of information that will be made available to accounting users through demonstrations and reports.

The article 3 in the AFB Resolution 750/93 stablishes as elemental principles of accounting: Entity, Continuity, Opportunity, Cost Principle, Competence and Prudence. The AFB Resolution 1282/10 revoked the principle of monetary correction, and since, it has not been part of the roll of accounting principles. The Entity principle states that entities' and partners' or company owners' equity must be distinguished, prioritizing individuality. The Continuity principle comprises the considerations over the life cycle, continuous or probable, of the entity during the period of evaluation of its equity elements.

Article 6 The Opportunity principle refers to, simultaneously, the agility and integrity of equity register and its alterations, demanding its immediate formalization according to the correct extension, without regards to the causes that have originated them.

Article 7 The components of equity must be registered by their original value of transactions with the external world, expressed in the country's present currency value, and those will be maintained in the evaluation of future equity alterations, in as much as when alterations represent aggregations or decomposition to the interior of the ENTITY. (CFC, 2008).

The Competence principle states that the accounting events which produce expenses and revenues must be registered temporarily when their originating facts take place, irrespective of the effective recipiency or payment. The last principle, Prudence, asserts that in case of doubt, the scenario that demonstrates the smallest possible equity to the entity must be the one considered. Thus, since there is no guarantee of the values that need validation, the assets and revenues must be registered using the one of lowest monetary value, on the other hand, liabilities and expenses using those of highest value (CFC, 2008).

We do not regard the companies' equity integrally as a reflection of their economic and operational status overlooking the possible impacts of their operation to the environment. Such impacts may bring about outlays as fines, reimbursement liabilities and/or demand environment recovery. Thus, the environmental accounting has a beneficial function of informing users about the level of environmental hazard the entities carry, indicating in their demonstrations the extension, the materiality and reductive measures for those risks.

So, according to Ferreira (2009), "it is important to highlight that environmental accounting does not represent a new accounting science, but a set of information that properly reports, in economic terms, the actions of an entity that modify their equity. This set of information is not another Science[...]". Since it is not a new science, it is subjected to the same practices and principles of the traditional accounting, and that condition is compulsory to maintain uniformity and coherence to the accounting science. That means the 
basic principles which are valid for traditional accounting must be equally valid to the disclosure of environmental facts. Nevertheless, the awareness that has been developed over environmental sustainability carries in its scope particular principles and grounds to which other areas of knowledge must adjust in order to introduce the subject of sustainability into their areas of performance.

Through the Agenda 21 (A21), the United Nations and their State Members stablished a set of principles that must adopted in favor of environmental sustainability, and it was sanctioned in Brazil and followed in the country by the Policies Commission on Sustainable Development and the National Agenda 21 (CPDS, 2002). The Agenda 21 is directed specifically to the national States, the obligations and duties countries hold regarding sustainability are mentioned in most items, with recommendations to stablish specific legislation conducted to this purpose; at this point companies must identify the main measures the Agenda 21 demands them. Among these matters, 9 (nine) of them, in our view, as discussed further, are the ones that directly affect companies and their operation, indicating what to do and not to do in their quest for the environmental balance of their activities. These presumptions will directly cause an effect in the entities' equity and must guide the interaction of measurement, register and demonstration activities of the accounting environmental information.

According to Agenda 21, sustainability must be conceived as the right for present and future generations of a balanced environment and a poverty-free social condition (Principle number 3 A21). Therefore, environmental protection is one of the elements that integrate development, and must not be regarded as an external element to it (Principle number 4 A21). Sustainability is, then, a necessary presumption to the progression of present and future human generations, and consequently, also to the continuity of economic organizations. The discontinuance of the former impairs that of the latter, in consequence, environmental sustainability is a condition to business sustainability. Environment protection must be integrated to development, since they represent a whole, their role is understood as indissoluble. Thereupon, the equity development of an entity should not disregard the environment it is inserted in. The organization's equity may be detached from other organizations', but it is integrated to environmental conditions in order to exist. It is noticeable the Continuity and Entity Principles are correlated to Sustainability principles (RIBEIRO, 2006).

One of the measures to guarantee sustainability is to reduce or eliminate production processes that are environmentally unsustainable, in other words, which produce environmental instability, targeting the extinction of any negative impact to nature (Principle number 8 A21). It states that the best way to treat environmental issues is through ample participation, therefore, providing the directly or indirectly affected citizens with information on environmental impacts, this kind of awareness guarantees instruments for lawsuits and administrative actions in order to compensate and repair damage (Principle number 10 A21) (CPDS, 2002; BARBIERI, 2008).

Governments must adopt environmental legislation that institute environmental norms, objectives and priorities (Principle number 11 A21). These must determine culpability to environmental damage agents and the liability to reimburse victims (Principle number 13 A21), enacting principles of agents' precaution to 
the environment (Principle number 15 A21), the principle of the commitment to pay for caused damage, and also environmental recovery (Principle number $16 \mathrm{~A} 21$ ) and also of promoting previous evaluations of the confirmed or potential impacts of the productive activities (Principle number 17 A21) (CPDS, 2002; BARBIERI, 2008).

The collective of A21 principles correlate to the accounting principles of Prudence, Competence, Opportunity and Cost. The adoption of measures to reduce the environmental impacts has a cautious connotation regarding the obligations of repairing and recovering damage, which would result in the future reduction of negative impacts over equity. Consequently, Competence involves the direct relationship between the entity's liability regarding the environmental damage it causes: the occurrence of an environmental fact corresponds to an equity operation intended to recover and reimburse damages. The Competence principle is equally associated to the preventive outlays which aim to the precaution of possible risks. Under that condition, the registered environmental facts also have a cautious connotation, as discussed before. Every outlay or environmental implemented measure corresponds to the application of an amount of resources, and the value will be the register origin. So, the accounting Cost principle is preserved.

Although a future event amount may not be precisely determined, based on the Prudence principle, it might be estimated by using several methodologies and, then, when it is decisively measured, the estimated value ought to be adjusted. That correlates to the Opportunity principle. Following the measurement of the applied amount to damage prevention, recovery and repairing, it must be immediately counted. However, if there is no precise measurement, and the risk of environmental damage has been acknowledged as real or potential, it is advisable it is estimated and identified in disclosure to users of the accounting information.

From this evidence, it is possible to claim that there is no incompatibility between the accounting principles and sustainable ones. Enabling the disclosure of companies' environment-related facts using accounting, in accordance to principles of both areas. In addition to acting as signatory country in the Agenda 21, Brazil has effectively incorporated several of its elements to the country's legislation in regard to companies' and organizations' economic activities. There has been jurisprudence over innumerous cases, in which the entities had to pay large amount of financial resources in indemnification, damage prevention and damage repairing suits.

Ramos (2016) states that the Brazilian Constitution and infraconstitutional regulations, regarding the Agenda 21, are led by principles of precaution, prevention, repairing, polluter pays, responsibility and several norms about limitation in emission of pollutants. Furthermore, large companies must elaborate studies and reports on environmental impacts and request specific authorization in previous stages and during the operationalization of the businesses.

All these elements reinforce how the environmental sustainability is permeating the organizational activity, as a result of the liabilities resulting from previous studies, environmental hazard reports, investment in impact prevention, penalties imposed to indemnification and damage repairing. They represent actions with effects over companies' equity, over their profitability and even their continuity (FERREIRA, 2009). 
Therefore, the accounting of environmental information about the business organizations is relevant to investors and holders so that they can evaluate their business risks; to the government about critical areas and entities to promote inspection procedures, to implement specific policies and guarantee citizens' constitutional right to a balanced environment; and to society and consumers, giving them access to data about the level of responsibility and the institutions risks regarding the environment as a result of their operation.

The Accounting Federal Board also sets qualitative premises, named presumptions, that the accounting information must contain and must be conjugated to the principles during the interpretation of accounting facts to disclosure. It is also advantageous to correlate them to sustainability fundaments. The AFB (2008) issued the Resolution 1121/08 which instituted the Brazilian Accounting Norm NCB T-1, which is related to the conceptual structure to the elaboration and presentation of accounting demonstrations. It aimed to conciliate the Brazilian Accounting to international norms, providing qualitative criteria to evaluate accounting information. According to the guidelines, the information must present characteristics that guarantee uniformity to the practice among professionals to ensure a better comprehension by users. These are: comprehension, relevance, materiality, reliability, adequate representation, priority to essence over form, neutrality, prudence, integrity, comparability, time period assumption, cost-benefit balance.

Therefore, by accounting the environment-related information the correspondence to these presumptions must be as accurate as possible. Accuracy is a basic condition to validation, respecting the accounting principles. These must be addressed to their fullest, but the presumptions allow more flexibility regarding their application, and the relevance, materiality and urgency of the information are considered at the moment of disclosure. The thing is, the more adequate the presumptions are, higher is the quality of the accounting information and more useful it will be to users (SÁ, 2002).

The information generated in Accounting must be understandable by users (comprehension) and useful to decision-making process (relevance) about facts which affect or influence the entities' activities regarding their qualitative or quantitative aspects (materiality). For that to happen, the information must be accurate, precise or as close as possible to reality (reliability and adequate representation). The accounting information must prioritize the essence or purpose of acts that affect the equity over structure (Priority to essence over form); on that matter, the register must represent the original purpose of the acts and not the legal way it is performed, always seeking to provide reliable information about the facts and refraining from misleading or biased information (neutrality), however, it cannot implicate prudence regarding the events that originate doubts or multiple interpretations, what demands precaution and conservatism in evaluations (prudence). "Information included in accounting demonstrations needs completeness to be reliable, within the limits of materiality and cost" (integrity)(CFC, 2008).

The entities equity is dynamic, consequently the comparison between their situation and operations eventually is fundamental to the understanding of their evolution and performance (comparability), as well as in comparison to other entities. For that reason, the adopted criteria cannot be frequently modified and, when they are altered, the effects which affect the equity must always be informed. The extent at which the 
information is useful is influenced by its potential to portray the real situation of the equity at the moment they are acknowledged (time period assumption), because non-recent data about a specific fact has little usage to user when decisions need to be made. Lastly, information needs to be detailed so that the necessary cost to obtain it justifies the benefit or utility provided by it. Every information demands a human and financial cost to be obtained. When the relation between cost and benefit is not advantageous, the information is not worth it (cost-benefit balance).

To address these accounting presumptions, the environmental facts may be divided into two distinct categories. The first one encompassing material and present facts; the second one with future and potential facts. For instance, the entity, in accordance to the legislation in force or to a particular sustainable policy, might perform a series of preventive and precautious activities. The equity movements resulted from them may be easily registered in conformity to all accounting requirements: understandable, relevance, material, reliable, adequately represented, giving priority to essence over form, neutral, prudent, integral, advantageous cost-benefit balance, time period assumed and comparable to other entities.

The actions to repair environmental impacts, even when applicable as penalties by public power in accordance to the Polluter Pays and Responsibility principles, they can be in disclosure with all those requirements. Due to the fact that there are documental databases to nourish the accounting entries. These databases would be supplied with the fines convicted in public administration or lawsuit procedures, as well as the amount of outlays incurred to the execution of repairing operations to the environment and local population. That is, the value effectively spent by the company to repair the caused damage (RIBEIRO, 2006; RAMOS, 2016).

However, the operation becomes more complex when it comes to recognizing future events. Initially, it is not easy to measure the economic impact of a possible future episode unaware of its essence, extension and intensity. This kind of condition lack technical elements to ensure reliable, material, relevant, integral, comparable, properly represented, understandable and cost-effective information to users. Notwithstanding, the Agenda 21 defends that lack of technique may not be a rationale to non-sustainable practices and the Polluter pays principle, fatally, assigns liabilities to entities (RAMOS, 2016). A legal understanding that, necessarily, enforces the entity to incur outlays and their effects over equity. Thereby, prudence needs to be considered in accounting. The entity's awareness that a future occurrence may have an impact on the environment already determines the opportunity and time period assumption that they need to be measured (RIBEIRO, 2006).

The question lays, as mentioned before, in the measurement of futures events since their essence, extension and dimension are not exactly defined. Nonetheless, accounting admits the use of estimates for future events. Since a clear methodology is used, and it is properly demonstrated through Explanatory Notes to the accounting demonstrations, it is possible to measure estimated values for future events. By using specific compensational and provisioning accounts, the values might be included in accounting demonstrations (SÁ, 2002; NEVES, 2013; CFC, 2008). 
Unlike aleatory predictions, the values are obtained from more reliable and secure criteria in regard to the judgment of what is adequate to the situation in disclosure. Under these circumstances, accountants may use data from other companies as reference when area of performance, size, technology of processes, activities and so on allows a comparison to the company in analysis. It is also possible to use of information from entities that caused environmental impacts and have performed repairing, recoveries and indemnification payments. As long as the used criteria is described, the calculus of estimates based in the analogy with other entities is valid. Thus, it is possible to consider an entity from a similar area (Alpha company) of business which suffered certain incident in its operation, and the repairs accounted for $\$ X$. The company then identifies that the Alpha company spent an amount of $\$ X$, and that the same kind of incident might be incurred to it, then, it is understandable that it suffers a similar economic impact. What risks are involved provided this happens?

When a tolerable risk margin is set, then the amount is calculated and presented as provision, expected and explained in specific notes or even as an explanatory note in a particular report, irrespective of accounting demonstrations. From that, companies might institute programs which addresses to reduce such occurrence of risks. Thus, it is regarded as an environment-related preventive outlay. That is, disclosure of an initiative motivated by an environmental action even with future economic effect, such idea is supposed to be regarded as indissoluble in environmental accounting.

\section{CONCLUSIONS}

Based on this research, we may assume that the fundamental accounting principles and presumptions agree with the environmental sustainability fundaments. Hence, disclosure of environmental accounting facts correlates to that of traditional accounting. The theoretical foundations that both areas, traditional and environmental, anchor in are equally and correspondingly valid.

On that matter, the fundamental theoretical resources to the operationalization of accounting is onefold, since environmental accounting is not regarded as a new science, it is merely the incorporation of a series of facts that not long ago were overlooked and denied as part of companies' and organizations' operation: the environmental dimension of their activities and their impact over equity.

The obsolete belief that environmental damage resulted from companies' activities were an outcome to be tolerated by all is not socially accepted any longer. The Brazilian environmental legislation mandates companies' liability to prevent, limit and recover ecological impacts their operation might cause. This means their environmental impacts must be internalized. This information cannot be restricted to entities' management, it must be shared with everyone it may interest. They are: investors, the State, and society. Nevertheless, they haven't been properly informed about companies' environment-related information yet, apart from environmental reports which spread sustainability operations.

However, these reports do not truthfully demonstrate the impacts the organization's activities cause in the environment and how they might affect the company's equity and, consequently, their financial status and continuity. These pieces of information are extremely important and tend to be more relevant and 
present for companies which intend to follow paths society and the environment have demanded for the past couple of decades, thus, accounting must internalize this sort of understanding in accomplishing its social function.

\section{REFERENCES}

CFC. Conselho Federal de Contabilidade. Princípios Fundamentais e Normas Brasileiras de Contabilidade, de Auditoria e Perícia. Brasília: CFC, 2008.

CFC. Conselho Federal de Contabilidade. Resolução no 1282/2010. Brasília: CFC, 2010.

CFC. Conselho Federal de Contabilidade. Resolução no 750/1993. Brasília: CFC, 1993.

BRASIL. Comissão de Políticas de Desenvolvimento Sustentável e Agenda 21 Nacional. Agenda 21 brasileira. Brasília, 2002

BARBIERI, J. C.. Desenvolvimento e Meio Ambiente: as estratégias de mudanças da Agenda 21. 9.ed. Petrópolis: Vozes, 2008.

BEBBINGTON, J.; GRAY, R.; THOMSON, I.; Walters, D. Accountants' attitudes and environmentally-sensitive accounting. Accounting and Business Research, v.24, n.94, p.109-120, 1994. DOI:

http://doi.org/10.1080/00014788.1994.9729470

BRASIL. Ministério da Educação. Resolução CNE/CES n. 10: Institui as Diretrizes Curriculares Nacionais para o Curso de Graduação em Ciências Contábeis, bacharelado, e dá outras providências. Brasília: DOU, 2004.

CERQUEIRA, J. P.; MARTINS, M. C.. Auditorias de Sistemas de Gestão: ISO 9001, ISO 14001, OHSAS 18001, ISSO/IEC 17025, SA 8000, ISO 19011:2002. Rio de Janeiro: Qualitymark, 2004.

COSENZA, J. P.. Breve panorama da contabilidade socioambiental. Revista de Contabilidade do Mestrado em Ciências Contábeis da UERJ, Rio de Janeiro, v.17, p.104, 2012.
FERREIRA, A. C. S.. Contabilidade Ambiental. 2 ed. São Paulo: Atlas, 2009.

GIL, A. C.. Métodos e Técnicas de Pesquisa Social. 6 ed. São Paulo: Atlas, 2009.

GOMES, S. M. S.; SAMPAIO, M. S.; AZEVEDO, T. C.; SLOMSKI, V. G.. Proposta para o ensino da controladoria ambiental nos cursos de graduação de ciências contábeis nas IES brasileiras. Revista de Gestão Social e Ambiental - RGSA, São Paulo, v.6, n.1, p.177-189, 2012. DOI: http://doi.org/10.5773/rgsa.v6i1.403

NASCIMENTO, L. F.; LEMOS, Â. D. C.; MELLO, M. C. A.. Gestão Socioambiental Estratégica. Porto Alegre: Bookman, 2008.

NEVES, S.; VICECONTI, P. E. V.. Contabilidade Avançada: e análise das Demonstrações Financeiras. 17 ed. São Paulo: Saraiva, 2013.

RAMOS, E. M. B.. O Direito Ambiental e os Princípios da Sustentabilidade: uma breve análise histórico-jurídica. Revista do CEDS, v.1, n.4, 2016.

RIBEIRO, M. S.. Contabilidade Ambiental. São Paulo: Saraiva, 2006.

SÁ, A. L.. Teoria da Contabilidade. 3 ed. São Paulo: Atlas, 2002.

SILVA, B. G.. Contabilidade Ambiental: Sob a ótica da contabilidade financeira. Curitiba: JRUA LV, 2008.

SMITH, A.. A Riqueza das Nações: Investigação sobre sua natureza e suas causas. 2 ed. São Paulo: Nova Cultural, 1985.

VASCONCELOS, E. M.. Complexidade e Pesquisa

Interdisciplinar: epistemologia e metodologia operativa. 2 ed. Petrópolis: Vozes, 2002.

A CBPC - Companhia Brasileira de Produção Científica (CNPJ: 11.221.422/0001-03) detém os direitos materiais desta publicação. Os direitos referem-se à publicação do trabalho em qualquer parte do mundo, incluindo os direitos às renovaç̃oses, expansões e disseminações da contribuiç̃o, bem como outros direitos subsidiários. Todos os trabalhos publicados eletronicamente poderão posteriormente ser publicados em coletâneas impressas sob coordenação da Sustenere Publishing, da Companhia Brasileira de Produção Científica e seus parceiros autorizados. Os (as) autores (as) preservam os direitos autorais, mas não têm permissão para a publicação da contribuição em outro meio, impresso ou digital, em português ou em tradução. 